\title{
Physicochemical stability of nefopam and nefopam/ droperidol solutions in polypropylene syringes for intensive care units
}

\author{
Elise D’Huart, ${ }_{1}^{1}$ Jean Vigneron, ${ }^{1}$ Igor Clarot $_{1}{ }^{2}$ Béatrice Demoré ${ }^{1,3}$
}

\begin{abstract}
- Additional material is published online only. To view please visit the journal online (http://dx.doi.org/ 10.1136ejhpharm-2019001856).
\end{abstract}

${ }^{1}$ Pharmacy, Centre Hospitalier Universitaire de Nancy, Vandoeuvre-lès-Nancy, France ${ }^{2}$ Laboratoire CITHEFOR, Université de Lorraine, Nancy, France

${ }^{3}$ EA 4360 APEMAC, Université de Lorraine, Nancy, France

\section{Correspondence to} Elise D'Huart, Pharmacy, Centre Hospitalier Universitaire de Nancy, Vandoeuvre-lèsNancy, France; dhuartelise@ gmail.com

Preliminary data were accepted as a poster during the 24th EAHP Congress in Barcelona, Spain in March 2019.

Received 7 January 2019 Revised 9 April 2019 Accepted 8 May 2019 Published Online First 11 June 2019

\section{EAHP Statement 5: Patient} Safety and Quality Assurance.

\begin{abstract}
Introduction Nefopam has been reported to be effective in postoperative pain control with an opioidsparing effect, but the use of nefopam can lead to nausea and vomiting. To prevent these side effects, droperidol can be mixed with nefopam. In intensive care units, high concentrations of nefopam and droperidol in syringes can be used with a continuous flow.

Objectives The first objective of this work was to study the physicochemical stability of a nefopam solution 2.5 $\mathrm{mg} / \mathrm{mL}$ diluted in $\mathrm{NaCl} 0.9 \%$ in polypropylene syringes immediately after preparation and after 6, 24 and 48 hours at room temperature. The second objective was to study the physicochemical stability of mixtures of nefopam $2.5 \mathrm{mg} / \mathrm{mL}$ and droperidol $52 \mu \mathrm{g} / \mathrm{mL}$ diluted in $\mathrm{NaCl} 0.9 \%$ in polypropylene syringes at room temperature over 48 hours.

Materials and methods Three syringes for each condition were prepared. For each time of analysis, three samples for each syringe were prepared and analysed by high performance liquid chromatography coupled to photodiode array detection. The method was validated according to the International Conference on Harmonisation Q2(R1). Physical stability was evaluated by visual and subvisual inspection (turbidimetry by UV spectrophotometry). pH values were measured at each time of analysis.

Results Solutions of nefopam at $2.5 \mathrm{mg} / \mathrm{mL}$ and the mixture of nefopam $2.5 \mathrm{mg} / \mathrm{mL}$ with droperidol $52 \mu \mathrm{g} /$ $\mathrm{mL}$, diluted in $\mathrm{NaCl} 0.9 \%$, without protection from light, retained more than $90 \%$ of the initial concentration after 48 hours storage at $20-25^{\circ} \mathrm{C}$. No modification in visual or subvisual evaluation and $\mathrm{pH}$ values were observed. Conclusion Nefopam solutions at $2.5 \mathrm{mg} / \mathrm{mL}$ and the mixture of nefopam $2.5 \mathrm{mg} / \mathrm{mL}$ with droperidol $52 \mu \mathrm{g} /$ $\mathrm{mL}$ diluted in $\mathrm{NaCl} 0.9 \%$ were stable over a period of 48 hours at room temperature. These stability data provide additional knowledge to assist intensive care services in daily practice.
\end{abstract}

\section{INTRODUCTION}

Nefopam is a centrally acting non-opioid analgesic drug. ${ }^{1}$ It has been reported to be effective in postoperative pain control with an opioid-sparing effect. The use of opioids is often associated with a high incidence of postoperative nausea and vomiting. ${ }^{2}$ However, nefopam itself can induce postoperative nausea and vomiting. ${ }^{3}$ In our hospital, to prevent these side effects, droperidol is mixed with nefopam solutions in a polypropylene syringe. Droperidol is a dopamine $\mathrm{D}_{2}$ receptor antagonist in the chemotrigger zone, in the area postrema, which gives it a potent antiemetic effect. This drug is indicated to prevent and treat postoperative nausea and vomiting. The usual dose of droperidol per dose is $1.25 \mathrm{mg}$ and repeated doses may be given every 6 hours as required ${ }^{4}$; the maximum daily dose of nefopam should not exceed $120 \mathrm{mg}^{5}$

In clinical practice in intensive care units, nurses use a final volume of $48 \mathrm{~mL}$ in syringes to achieve an accurate flow rate of $2 \mathrm{~mL} /$ hour over 24 hours. They often use high concentrations of drug solutions with a minimum volume to avoid fluid overload. In our hospital, the maximum daily dose of nefopam $(120 \mathrm{mg})$ is usually mixed with droperidol in a syringe with a final volume of $48 \mathrm{~mL}$, resulting in concentrations of nefopam of $2.5 \mathrm{mg} / \mathrm{mL}$ and of droperidol of $52 \mu \mathrm{g} / \mathrm{mL}$.

In the literature, to the best of our knowledge, no stability or compatibility study of a mixture of nefopam and droperidol or a nefopam solution in polypropylene syringes has been published. McClusey et al studied the stability of a droperidol solution at $0.625 \mathrm{mg} / \mathrm{mL}$ in $0.9 \%$ sodium chloride $(\mathrm{NaCl} 0.9 \%)$ in polypropylene syringes and determined 180 -day stability at $23-27^{\circ} \mathrm{C}$ when protected from light. ${ }^{6}$

The spontaneous degradation of nefopam leads to a diol which is the major degradation compound of this analgesic.?

The first objective of this work was to study the physicochemical stability of a nefopam solution at $2.5 \mathrm{mg} / \mathrm{mL}$ diluted in $\mathrm{NaCl} 0.9 \%$ in polypropylene syringes immediately after preparation and after 6 , 24 and 48 hours at room temperature. The second objective was to study the physicochemical stability of a mixture of nefopam at $2.5 \mathrm{mg} / \mathrm{mL}$ and droperidol at $52 \mu \mathrm{g} / \mathrm{mL}$ diluted in $\mathrm{NaCl} 0.9 \%$ in polypropylene syringes at room temperature over 48 hours.

\section{MATERIALS AND METHODS \\ Chemicals and reagents}

Monopotassium phosphate $\mathrm{KH}_{2} \mathrm{PO}_{4}$ (Merck, batch: AM09735277618), orthophosphoric acid 85\% (VWR Chemicals, batch: 15D200503), heptane sulfonic acid sodium salt (VWR Chemicals, batch: 18E184103), trimethylamine (VWR Chemicals, batch: 14J280506) and acetonitrile (VWR Chemicals, batch: D7G058267G, D5N045046A) were used for the mobile phase. Hydrochloric acid 1.0M (VWR Chemicals, batch: 17110005), hydrochloric acid 0.1 M (VWR Chemicals, batch: 17110001), sodium hydroxide 1.0M (VWR Chemicals, batch: 17110003), sodium hydroxide $0.1 \mathrm{M}$ (VWR Chemicals, batch: 17110001) and hydrogen peroxide 
30\% (Merck; batch: K48743810713) were used. Water for chromatography was obtained from a reverse osmosis system (Millipore Iberica, Madrid, Spain). Nefopam $20 \mathrm{mg} / 2 \mathrm{~mL}$ solution for infusion concentration (Medisol, batch H1030), droperidol $1.25 \mathrm{mg} / 1 \mathrm{~mL}$ (Aguettant, batch 4303323) and $0.9 \% \mathrm{NaCl}$ $500 \mathrm{~mL}$ in glass vials (Lavoisier, batch: 8F390) were used for the validation of the analytical method and for the stability study.

\section{Preparation of test solutions}

For the preparation of a nefopam solution at $2.5 \mathrm{mg} / \mathrm{mL}$, six ampoules of nefopam at $20 \mathrm{mg} / 2 \mathrm{~mL}$ were used and completed with $0.9 \% \mathrm{NaCl}$ in polypropylene syringes to obtain a final volume of $48 \mathrm{~mL}$. For the preparation of a mixture of nefopam at $2.5 \mathrm{mg} / \mathrm{mL}$ and droperidol at $52 \mu \mathrm{g} / \mathrm{mL}$ in polypropylene syringes, six ampoules of nefopam at $10 \mathrm{mg} / \mathrm{mL}$ and two ampoules of droperidol at $1.25 \mathrm{mg} / \mathrm{mL}$ were used and then diluted with $0.9 \% \mathrm{NaCl}$ to obtain a final volume of $48 \mathrm{~mL}$. These solutions were stored in polypropylene syringes (BD Plastipak, $50 \mathrm{~mL}$ Luer-lok batch: 1808208). Three syringes were prepared for the two conditions. The syringes were stored at room temperature $\left(20-25^{\circ} \mathrm{C}\right)$, not protected from light.

\section{HPLC assay}

Nefopam solutions and the nefopam/droperidol mixture were analysed by a stability-indicating reversed-phase highperformance liquid chromatography (RP-HPLC) method with photodiode array (PDA) detection.

The HPLC system consisted of an ELITE LaChrom VWR/ Hitachi plus autosampler, a VWR PDA detector L-2455 and a VWR L-2130 HPLC pump. Data were acquired and integrated using EZChrom Elite (VWR, Agilent). The column used was LiChrospher 100 RP-18, LiChroCART 125-4, $12.5 \mathrm{~cm}$ length, $5 \mu \mathrm{m}$ particle size (Analytical Chromatography, Merck). ${ }^{8}$ The mobile phase consisted of $25 \%$ acetonitrile and $75 \%$ phase A, which is composed of $25 \% \mathrm{KH}_{2} \mathrm{PO}_{4}$ buffer at $0.2 \mathrm{M}$ with 0.01 $\mathrm{M}$ heptane sulfonic acid sodium salt and $1 \mathrm{~mL} / \mathrm{L}$ trimethylamine, adjusted to $\mathrm{pH} 3.0$ with orthophosphoric acid $85 \%$.

The flow rate was set at $2 \mathrm{~mL} / \mathrm{min}$ with an injection volume of $10 \mu \mathrm{L}$. The detection wavelength was set at $225 \mathrm{~nm}$ for nefopam and $246 \mathrm{~nm}$ for droperidol. The temperature of the injector was set at $15^{\circ} \mathrm{C}$ and the temperature of the column oven at $30^{\circ} \mathrm{C}$. The calibration curve was constructed from plots of peak area versus concentration. The linearity of the method was evaluated at five concentrations (nefopam: $0.75,1.0,1.25,1.5$ et $1.75 \mathrm{mg} / \mathrm{mL}$; droperidol: 15, 20, 25, 30 and $35 \mu \mathrm{g} / \mathrm{mL}$ ).

A mixture of nefopam $2.5 \mathrm{mg} / \mathrm{mL}$ and droperidol $50 \mu \mathrm{g} / \mathrm{mL}$ was prepared and diluted in ultrapure water. This mixture was used to realise standard curves by dilution with ultrapure water. The intra-day reproducibility was evaluated as recommended by the International Conference on Harmonisation (ICH) Q2 $(\mathrm{R} 1)^{9}$ using three determinations for each concentration at (nefopam/droperidol) $0.75 \mathrm{mg} / \mathrm{mL} / 15 \mu \mathrm{g} / \mathrm{mL}, 1.25 \mathrm{mg} / \mathrm{mL} / 25$ $\mu \mathrm{g} / \mathrm{mL}$ and $1.75 \mathrm{mg} / \mathrm{mL} / 35 \mu \mathrm{g} / \mathrm{mL}$. For inter-day precision, three determinations for each concentration at (nefopam/droperidol) $0.75 \mathrm{mg} / \mathrm{mL} / 15 \mu \mathrm{g} / \mathrm{mL}, 1.25 \mathrm{mg} / \mathrm{mL} / 25 \mu \mathrm{g} / \mathrm{mL}$ and $1.75 \mathrm{mg} /$ $\mathrm{mL} / 35 \mu \mathrm{g} / \mathrm{mL}$ were prepared and assayed daily on three different days.

Evaluation of the stability in the autosampler was performed. Solutions of nefopam and droperidol diluted in ultrapure water were stored in the autosampler at $15^{\circ} \mathrm{C}$. Chemical stability was evaluated at different times up to hours.

The diode array detector allows the evaluation of the UV spectrum of the chromatographic column effluent every $0.4 \mathrm{~s}$, thus allowing evaluation of the UV purity of an eluting peak. Variations in the UV spectrum over the elution profile of the peak of interest would indicate that the peak is contaminated, that the analytical method does not separate nefopam and droperidol from their degradation products, and that the method is therefore unsuitable. ${ }^{10}$

The stability-indicating capability was evaluated by analysing forced degraded nefopam solutions and droperidol solutions.

\section{Acidic conditions}

For nefopam, $1 \mathrm{~mL}$ of a $5.0 \mathrm{mg} / \mathrm{mL}$ nefopam solution prepared in ultrapure water was diluted with $1.0 \mathrm{~mL} \mathrm{HCl} 0.2 \mathrm{M}$, stored for 24 hours at $80^{\circ} \mathrm{C}$, neutralised by $1.0 \mathrm{~mL} \mathrm{NaOH} 0.2 \mathrm{M}$ and diluted with $1 \mathrm{~mL}$ ultrapure water to obtain a theoretical concentration of $1.25 \mathrm{mg} / \mathrm{mL}$.

For droperidol, $1 \mathrm{~mL}$ of a $125 \mu \mathrm{g} / \mathrm{mL}$ droperidol solution prepared in ultrapure water was diluted with $1.0 \mathrm{~mL} \mathrm{HCl} 0.1$ $\mathrm{M}$ or $\mathrm{HCl} 0.2 \mathrm{M}$, stored for 24 hours at $80^{\circ} \mathrm{C}$, neutralised by $1.0 \mathrm{~mL} \mathrm{NaOH} 0.1 \mathrm{M}$ or $\mathrm{NaOH} 0.2 \mathrm{M}$, respectively, and diluted with $1.0 \mathrm{~mL}$ ultrapure water to obtain a theoretical concentration of $31.25 \mu \mathrm{g} / \mathrm{mL}$. Another batch was prepared by adding 1.0 $\mathrm{mL} \mathrm{HCl} 1 \mathrm{M}$ at $1 \mathrm{~mL}$ of a $125 \mu \mathrm{g} / \mathrm{mL}$ droperidol solution for 1 , 2 and 4 hours and diluted with $1.0 \mathrm{~mL} \mathrm{NaOH} 1 \mathrm{M}$ and $1.0 \mathrm{~mL}$ ultrapure water.

\section{Alkaline degradation}

For nefopam, $1 \mathrm{~mL}$ of a $5.0 \mathrm{mg} / \mathrm{mL}$ nefopam solution prepared in ultrapure water was diluted with $1.0 \mathrm{~mL} \mathrm{NaOH} 0.01 \mathrm{M}$ for $5 \mathrm{~min}$, neutralised by $1.0 \mathrm{~mL} \mathrm{HCl} 0.01 \mathrm{M}$ and diluted with 1.0 $\mathrm{mL}$ ultrapure water to obtain a theoretical concentration of 1.25 $\mathrm{mg} / \mathrm{mL}$.

For droperidol, $1 \mathrm{~mL}$ of a $125 \mu \mathrm{g} / \mathrm{mL}$ droperidol solution prepared in ultrapure water was diluted with $1.0 \mathrm{~mL} \mathrm{NaOH} 0.1$ $\mathrm{M}$, stored for 24 hours at $80^{\circ} \mathrm{C}$, neutralised by $1.0 \mathrm{~mL} \mathrm{HCl} 0.1$ $\mathrm{M}$ and diluted with $1.0 \mathrm{~mL}$ ultrapure water to obtain a theoretical concentration of $31.25 \mu \mathrm{g} / \mathrm{mL}$.

\section{Oxidative degradation}

One $\mathrm{mL}$ of a $5.0 \mathrm{mg} / \mathrm{mL}$ nefopam solution and $1 \mathrm{~mL}$ of a $125 \mu \mathrm{g} /$ $\mathrm{mL}$ droperidol solution were diluted with $1.0 \mathrm{~mL} \mathrm{H}_{2} \mathrm{O}_{2} 3.0 \%$, respectively, stored at $20-25^{\circ} \mathrm{C}$ for 1 hour and diluted with 2.0

Table 1 Results of the validation of the analytical method of nefopam and droperidol

\begin{tabular}{lllll}
\hline & Equation of calibration curve & Determination coefficient (R²) & Intra-day (RSD) & Intermediate precision (RSD) \\
\hline Nefopam & $y=36111.36 x-770270.3$ & 0.9998 & $(0.07-0.91 \%)$ & $0.75 \mathrm{mg} / \mathrm{mL}: 0.60 \%$ \\
& & & & $1.25 \mathrm{mg} / \mathrm{mL}: 0.69 \%$ \\
& & & $1.75 \mathrm{mg} / \mathrm{mL}: 0.54 \%$ \\
Droperidol & $y=47941.85 x-63531.5$ & 0.9998 & $(0.17-2.68 \%)$ & $15 \mu \mathrm{g} / \mathrm{mL}: 1.44 \%$ \\
& & & & $25 \mu \mathrm{g} / \mathrm{mL}: 1.52 \%$ \\
& & & $35 \mu \mathrm{gg} / \mathrm{mL}: 0.73 \%$ \\
\hline
\end{tabular}


$\mathrm{mL}$ ultrapure water to obtain a theoretical concentration of 1.25 $\mathrm{mg} / \mathrm{mL}$ and $31.25 \mu \mathrm{g} / \mathrm{mL}$, respectively.

\section{Heat degradation}

A solution of $1.25 \mathrm{~g} / \mathrm{mL}$ nefopam and a solution $31.25 \mu \mathrm{g} / \mathrm{mL}$ droperidol were exposed to a temperature of $80^{\circ} \mathrm{C}$ for 24 hours.

\section{Light degradation}

A solution of $1.25 \mathrm{mg} / \mathrm{mL}$ nefopam and a solution of $31.25 \mu \mathrm{g} /$ $\mathrm{mL}$ droperidol were stored under a sun-like spectrum lamp at $254 \mathrm{~nm}$ (Vilbert Lourmat) for $75 \mathrm{~min}$ and $10 \mathrm{~min}$, respectively.

\section{Sample dilution for analysis by RP-HPLC}

At each time of analysis, $5.0 \mathrm{~mL}$ were removed from each syringe. The solutions were diluted before analysis with ultrapure water to obtain a concentration of $1.25 \mathrm{mg} / \mathrm{mL}$ for nefopam and $25 \mu \mathrm{g} /$ $\mathrm{mL}$ for droperidol.

Samples were prepared in triplicate for each syringe. After dilution, each sample was analysed by RP-HPLC. This process was repeated after 6, 24 and 48 hours. Total run time was set at $17 \mathrm{~min}$. We adapted the analysis time after forced degradation. The analysis time was $30 \mathrm{~min}$ but no peak of degradation was observed after 14 min during the forced degradation.

Chemical stability was defined as not less than $90 \%$ of the initial nefopam and droperidol concentration and in relation with the evolution of potential degradation products. ${ }^{911}$

\section{$\mathrm{pH}$ measurement}

$\mathrm{pH}$ measurement was performed using a Bioblock Scientific $\mathrm{pH}$ meter. Analysis was carried out for each concentration and each solvent after preparation and after 6, 24 and 48 hours. $\mathrm{pH}$ values were considered to be acceptable if they did not vary by more than $1.0 \mathrm{pH}$ unit from the initial measurement. ${ }^{10}$ We measured $\mathrm{pH}$ for each syringe, for each condition.

\section{Determination of physical stability}

Physical stability was defined as the absence of particulate formation, haze, colour change and gas evolution. ${ }^{12}$ The samples were visually inspected against a white/black background with unaided eye at each analysis time. The subvisual aspect was assessed using a Safas Monaco UV mc ${ }^{2}$ spectrophotometer. The absorbance was measured at 350, 410 and $550 \mathrm{~nm}^{.}{ }^{12}$

\section{RESULTS}

\section{RR-HPLC}

Calibration curves for both drugs were linear. The results of the validation of the analytical method are presented in table 1.

For the evaluation of the stability in the autosampler, solutions were stable with a degradation rate less than $0.5 \%$ for each molecule during 24 hours.

The UV spectral purity of the nefopam peak in chromatograms of the degraded samples was compared with the spectrum of the undegraded sample of nefopam. The same process was performed for droperidol. These procedures were in accordance with the acceptance standard.

Stability-indicating capacity was proved by using various stressed conditions for two independent solutions of nefopam and droperidol. The retention time was $4.5 \mathrm{~min}$ for nefopam and $6.0 \mathrm{~min}$ for droperidol. The resolution between the two peaks was greater than 1.5 , which demonstrated an acceptable separation. The chromatogram of the mixture without stressed degradation is presented in figure 1. Figures 2 and 3 show nefopam

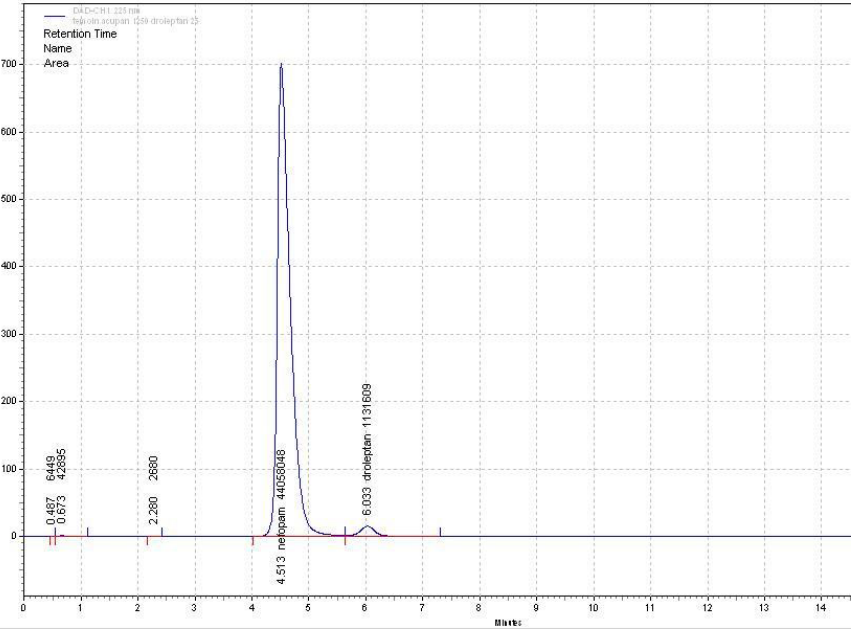

Figure 1 Chromatogram of a mixture of nefopam $2.5 \mathrm{mg} / \mathrm{mL}$ and droperidol $52 \mu \mathrm{g} / \mathrm{mL}$ in $0.9 \% \mathrm{NaCl}$ with detection at $225 \mathrm{~nm}$.

solution after acidic stressed conditions and droperidol solution after photolysis, respectively.

After acidic and UV stressed degradations, 20\% and 15\% of nefopam were degraded respectively. In alkaline conditions, the nefopam solution was precipitated and, in oxidative conditions, the nefopam solution was not degraded. After alkaline and UV stressed degradations, $30 \%$ and $21 \%$ of droperidol were degraded, respectively. In acidic and oxidative conditions, the droperidol solution was not degraded. In heat conditions, neither of the two molecules was degraded. No degradation products interfered with the molecules of interest. Mass balance of nefopam and droperidol, respectively, are shown in the online supplementary files.

\section{Chemical stability of solutions HPLC assay}

The percentage of nefopam diluted in $0.9 \% \mathrm{NaCl}$ at $2.5 \mathrm{mg} /$ $\mathrm{mL}$ after storage at $20-25^{\circ} \mathrm{C}$ for various time points is shown in table 2 . The percentage of the nefopam/droperidol mixture diluted in $0.9 \%$ is shown in table 3 . After 48 hours, nefopam

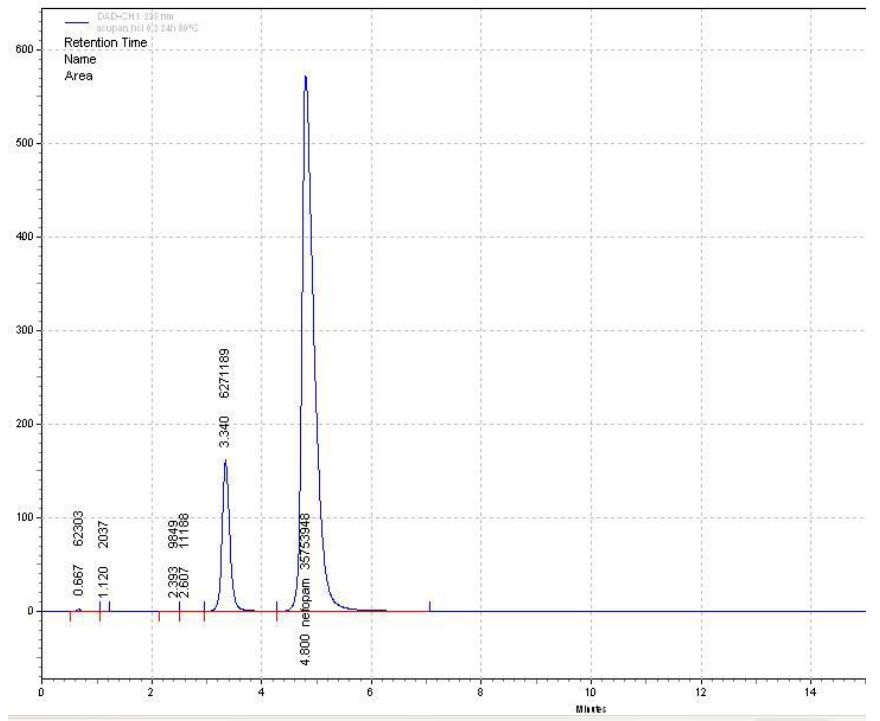

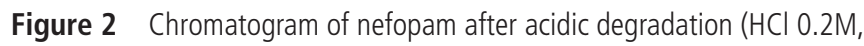
24 hours, $\left.80^{\circ} \mathrm{C}\right)$. 


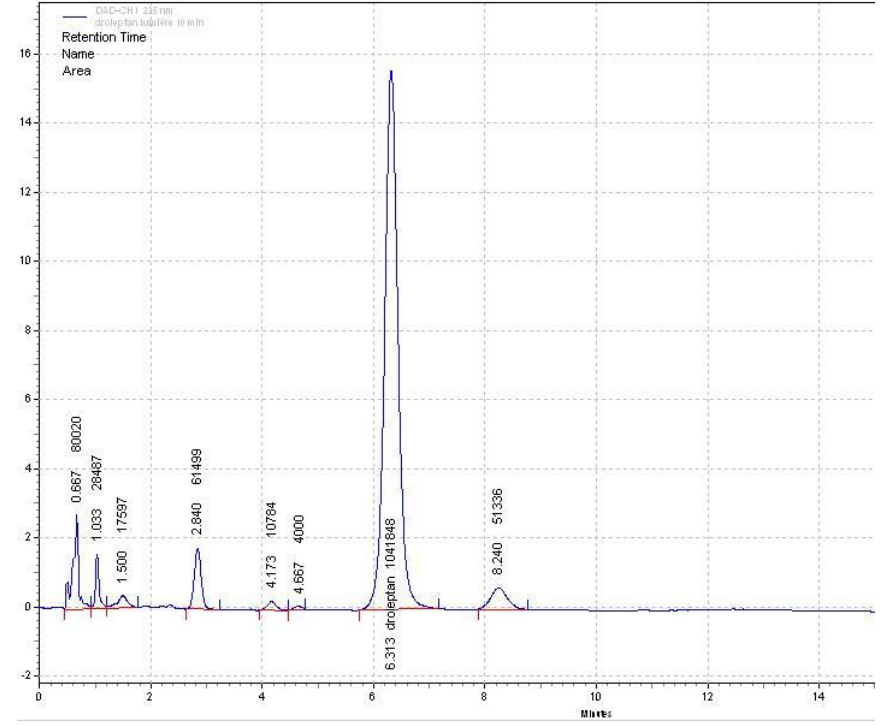

Figure 3 Chromatogram of droperidol after photolysis stressed conditions (10 $\mathrm{min})$

solutions or mixtures with droperidol in $0.9 \% \mathrm{NaCl}$ retained between $90.0 \%$ and $110.0 \%$ of the initial concentration. No additional peak was observed during the stability study.

\section{$\mathrm{pH}$ measurements}

During the study, for the nefopam-droperidol mixtures and for nefopam solutions, means ofpH values were $5.25 \pm 0.04$ and $5.34 \pm 0.03$ respectively.

\section{Physical stability of solutions}

Visual aspect

No visual modification was observed during the stability study for the nefopam solution and for the the mixture. Solutions remained limpid, without change of colour, precipitation or gas formation.

\section{Subvisual evaluation}

Concerning turbidity assays, no change was observed during the stability study for the mixture and the solution of nefopam. Whatever the storage conditions and the concentrations, values of absorbance at 350,410 and $550 \mathrm{~nm}$ remained inferior to $0.010 \mathrm{AU}$

\section{DISCUSSION}

This study showed that solutions of nefopam at $2.5 \mathrm{mg} / \mathrm{mL}$ and a mixture of nefopam $2.5 \mathrm{mg} / \mathrm{mL}$ with droperidol $52 \mu \mathrm{g} / \mathrm{mL}$, diluted in $\mathrm{NaCl} 0.9 \%$, without protection from light, retained more than $90 \%$ of the initial concentration after 48 hours storage at $20-25^{\circ} \mathrm{C}$.
During the forced degradation of droperidol, a degradation product with a retention time of $4.67 \mathrm{~min}$ (relative retention 0.74) was obtained. This time is close to the retention time of nefopam at $4.8 \mathrm{~min}$. During the stability study of nefopam, the purity of the nefopam peak was verified.

For the nefopam/droperidol mixture in syringe S2, the percentage obtained for nefopam and for droperidol after 6,24 and 48 hours storage is around $105 \%$ of the initial concentration. The hypothesis for this increase is related to a concentration value after the preparation that is small relative to the theoretical value. This may be due to a problem of homogenisation.

The stability of nefopam with another analgesic drug has already been investigated. Balayssac et al have demonstrated the stability of a mixture of nefopam and ketoprofen or paracetamol in binary or ternary for 24 hours at room temperature in glass vials. ${ }^{13}$ Hamdi et al studied the stability of a mixture of nefopam with ketoprofen, ketamine or acetaminophen, but the analytical method used for the determination of the chemical stability was not demonstrated to be stability-indicating at this time. ${ }^{14}$ No stability study of a nefopam mixture with a drug of the same pharmacological class has previously been performed.

The stability of droperidol with another analgesic drug has been evaluated. Chen et al demonstrated a 15-day stability for a mixture $0.08 \mathrm{mg} / \mathrm{mL}$ butorphanol tartrate and $0.05 \mathrm{mg} /$ $\mathrm{mL}$ droperidol in PVC bags at $25^{\circ} \mathrm{C}$ or between $2^{\circ} \mathrm{C}$ and $8^{\circ} \mathrm{C} .{ }^{15}$ Lebitasy et al determined the 32-day stability of a mixture of droperidol $0.025 \mathrm{mg} / \mathrm{mL}$ with tramadol hydrochloride $1 \mathrm{mg} / \mathrm{mL}$ between $2^{\circ} \mathrm{C}$ and $8^{\circ} \mathrm{C}$. ${ }^{16}$

Our study confirms the good stability of droperidol and adds new knowledge on the stability of nefopam.

\section{CONCLUSION}

Nefopam solutions at $2.5 \mathrm{mg} / \mathrm{mL}$ or a mixture of nefopam $2.5 \mathrm{mg} / \mathrm{mL}$ with droperidol $52 \mu \mathrm{g} / \mathrm{mL}$ diluted in $\mathrm{NaCl} 0.9 \%$ were physically and chemically stable over a period of 48 hours at room temperature. No modifications in visual or subvisual evaluation and $\mathrm{pH}$ values were observed during the stability study. These stability data of a highly concentrated solution provide additional knowledge to assist intensive care services in daily practice.

Acknowledgements The authors thank Jacques Kuhnlé for reading through the manuscript and making corrections, and Franck Blaise, Nathalie Sobalak and Hubert Zenier for their technical assistance and their help during this study.

Contributors EDH carried out the experiment and analysed the data. EDH wrote the manuscript with support from JV, IC and BD. JV supervised the project. All authors provided critical feedback.

Funding The authors have not declared a specific grant for this research from any funding agency in the public, commercial or not-for-profit sectors.

Competing interests None declared.

Patient consent for publication Not required.

Table 2 Stability of nefopam $2.5 \mathrm{mg} / \mathrm{mL}$ diluted with $0.9 \%$ sodium chloride $(\mathrm{NaCl} 0.9 \%)$

\begin{tabular}{llllll}
\hline & \multicolumn{2}{l}{ Initial nefopam concentration $(\mathrm{mg} /$} & \multicolumn{4}{l}{ Percentage of initial concentration \pm SD $(\%)$} & \\
\cline { 3 - 6 } Syringe & $\mathrm{mL})$ & $\mathbf{0}$ hour & 6 hours & 24 hours & 48 hours \\
\hline S1 & 2.60 & $100.00 \pm 0.26$ & $100.28 \pm 0.18$ & $100.53 \pm 0.02$ & $100.39 \pm 0.02$ \\
S2 & 2.58 & $100.00 \pm 0.22$ & $101.14 \pm 0.25$ & $100.86 \pm 0.12$ & $101.28 \pm 0.12$ \\
S3 & 2.61 & $100.00 \pm 0.15$ & $99.78 \pm 0.27$ & $100.28 \pm 0.27$ & $99.64 \pm 0.20$ \\
\hline
\end{tabular}

Note: Drug concentrations in samples taken at time zero were designated as $100 \%$. Samples were prepared in triplicate for each syringe. 
Table 3 Stability of a mixture of $2.5 \mathrm{mg} / \mathrm{mL}$ nefopam and $52 \mu \mathrm{g} / \mathrm{mL}$ droperidol diluted in $0.9 \%$ sodium chloride

\begin{tabular}{|c|c|c|c|c|c|c|}
\hline \multirow[b]{2}{*}{ Drug } & \multirow[b]{2}{*}{ Initial concentration } & \multirow[b]{2}{*}{ Syringe } & \multicolumn{4}{|c|}{ Percentage of initial concentration \pm SD $(\%)$} \\
\hline & & & 0 hour & 6 hours & 24 hours & 48 hours \\
\hline \multirow[t]{3}{*}{ Nefopam (mg/mL) } & 2.48 & S1 & $100.00 \pm 0.21$ & $102.04 \pm 0.22$ & $99.16 \pm 1.08$ & $100.59 \pm 0.54$ \\
\hline & 2.45 & S2 & $100.00 \pm 0.55$ & $104.40 \pm 0.25$ & $103.54 \pm 0.34$ & $105.27 \pm 0.53$ \\
\hline & 2.58 & S3 & $100.00 \pm 0.48$ & $99.89 \pm 0.38$ & $99.25 \pm 0.07$ & $100.65 \pm 0.02$ \\
\hline \multirow[t]{3}{*}{ Droperidol $(\mu \mathrm{g} / \mathrm{mL})$} & 56.08 & S1 & $100.00 \pm 0.21$ & $101.91 \pm 0.18$ & $98.52 \pm 0.83$ & $99.81 \pm 0.67$ \\
\hline & 54.44 & S2 & $100.00 \pm 0.69$ & $105.91 \pm 0.38$ & $104.03 \pm 0.78$ & $106.26 \pm 0.80$ \\
\hline & 57.01 & S3 & $100.00 \pm 0.49$ & $99.82 \pm 0.28$ & $99.25 \pm 0.38$ & $100.57 \pm 0.51$ \\
\hline
\end{tabular}

Note: Drug concentrations in samples taken at time zero were designated as $100 \%$. Samples were prepared in triplicate for each syringe.

\section{What this paper adds}

What is already known on this subject

- To prevent the side effects of nefopam, droperidol can be used.

- In the literature, to the best of our knowledge, no stability study of a nefopam/droperidol mixture in the same container or a nefopam solution highly concentrated has been published.

\section{What this study adds}

- Nefopam solutions at $2.5 \mathrm{mg} / \mathrm{mL}$ and a nefopam $2.5 \mathrm{mg} /$ $\mathrm{mL}$-droperidol $52 \mu \mathrm{g} / \mathrm{mL}$ mixture diluted in $\mathrm{NaCl} 0.9 \%$ were stable over a period of 48 hours at room temperature.

- These stability data provide additional knowledge to assist intensive care services in daily practice.

Provenance and peer review Not commissioned; externally peer reviewed.

Data sharing statement No data are available.

\section{REFERENCES}

1 Girard P, Chauvin M, Verleye M. Nefopam analgesia and its role in multimodal analgesia: a review of preclinical and clinical studies. Clin Exp Pharmacol Physiol 2016;43:3-12.

2 Oh C-S, Jung E, Lee SJ, et al. Effect of nefopam- versus fentanyl-based patientcontrolled analgesia on postoperative nausea and vomiting in patients undergoing gynecological laparoscopic surgery: a prospective double-blind randomized controlled trial. Curr Med Res Opin 2015;31:1599-607.
3 Heel RC, Brogden RN, Pakes GE, et al. Nefopam: a review of its pharmacological properties and therapeutic efficacy. Drugs 1980;19:249-67.

4 Droperidol PanPharma $2.5 \mathrm{mg} / \mathrm{mL}$. Solution for injection. Summary of product characteristics. 2016. PanPharma.

5 Nefopam Medisol $20 \mathrm{mg} / 2 \mathrm{~mL}$. Solution for perfusion. Summary of product characteristics 2017. Medisol.

6 Susan M V, Lovely Jenna K. Stability of droperidol $0.625 \mathrm{mg} / \mathrm{mL}$ diluted with $0.9 \%$ sodium chloride injection and stored in polypropylene syringes. Int I Pharm Compound 2011;15:170-3.

7 Wang DP, YH T, Allen LV, et al. Degradation mechanism of nefopam in solution under stressed storage conditions. Acta Pharm Nord 1990;2,2:73-82.

8 D'Huart E, Vigneron J, Clarot I, et al. Physicochemical stability of norepinephrine bitartrate in polypropylene syringes at high concentrations for intensive care units. Annales Pharmaceutiques Françaises 2019;77:212-21.

9 International Conference on Harmonisation. Validation of analytical procedures: text and methodology Q2 (R1)., 2005. Available: http://www.ich.org/fileadmin/Public Web_Site//CH_Products/Guidelines/Quality/Q2_R1/Step4/Q2_R1_Guideline.pdf [Accessed 23 Nov 2018].

10 Metha AC. Practice research: strategies for stability studies on hospital pharmaceutical preparations. Int J Pharm Pract 1993;2:49-52.

11 Sautou V, Brossard D, Chedru-Legros V, et al. Methodological guidelines for stability studies of hospital pharmaceutical preparations. SFPC and GERPAC. 1st edn, 2013: 75.

12 Bardin C, Astier A, Vulto A, et al. Guidelines for the practical stability studies of anticancer drugs: a European consensus conference. Annales Pharmaceutiques Françaises 2011;69:221-31.

13 Balayssac D, Badaroux L, Rodier C, et al. Compatibility and stability of parenteral analgesic admixtures for multimodal analgesia. EJHP Science 2009;15:78-82.

14 Hamdi M, Lentschener C, Bazin C, et al. Compatibility and stability of binary mixtures of acetaminophen, nefopam, ketoprofen and ketamine in infusion solutions. Eur J Anaesthesiol 2009;26:23-7.

15 Chen F-C, Fang B-X, Li P, et al. Compatibility of butorphanol and droperidol in $0.9 \%$ sodium chloride injection. Am J Health Syst Pharm 2013;70:515-9.

16 Lebitasy M, Hecq J-D, Vanbeckbergen $D$, et al. Long-term stability of tramadol hydrochloride and droperidol mixture in $5 \%$ dextrose infusion polyolefin bags at $5 \pm 3^{\circ} \mathrm{C}$. Annales Pharmaceutiques Françaises 2009;67:272-7. 